\title{
Waktu Efektif Pelaksanaan Pekerjaan Pembangunan Jaringan Reklamasi Rawa di Kotawaringin Barat
}

\author{
Trissiyana, Erdy Setiawan, Riki Ade Putra \\ Program Studi Teknik Sipil Fakultas Teknik \\ Universitas Antakusuma Pangkalan Bun
}

\begin{abstract}
ABSTRAK. Pembuatan rencana suatu proyek konstruksi selalu mengacu pada perkiraan yang ada saat rencana pembangunan, Penelitian ini dilakukan untuk mengetahui efisiensi pemberian waktu pelaksanaan pekerjaan oleh pemilik pekerjaan (owner) dan factor penghambat pekerjaan. Penelitian ini dilakukan pada proyek pembuatan jaringan reklamasi rawa di Kabupaten Kotawaringin Barat. Tujuan yang ingin dicapai dari analisis ini adalah (a) mengevaluasi efektivitas penetapan jangka waktu pelaksanaan proyek, (b) mengetahui waktu efektif rata-rata penyelesaian pekerjaan pembuatan saluran reklamasi rawa dan (c) mengetahui faktor-faktor umum yang sering menghambat penyelesaian pekerjaan. Objek penelitian adalah pihak-pihak yang menangani pekerjaan pembangunan jaringan reklamasi rawa di Kotawaringin Barat tahun 2012 dan 2013, yang terdiri dari pemilik kegiatan, pelaksana kegiatan, serta pengawas kegiatan. Metode penelitian yang dilakukan adalah penelitian survei dengan pengumpulan data menggunakan kuesioner. Berdasarkan hasil penelitian dapat disimpulkan bahwa (a) waktu efektif rata-rata penyelesaian pekerjaan pembuatan saluran reklamasi rawa adalah 67 hari, (b) waktu pelaksanaan proyek yang diberikan masih terlalu lama berdasarkan perbandingan antara waktu efektif rata-rata dengan waktu kontrak rata-rata yaitu 67 hari, sedangkan waktu kontrak rata-rata adalah 132 hari dan (c) tidak ada faktor yang masuk kategori tidak berpengaruh di mana peranannya hampir merata dalam menghambat penyelesaian pekerjaan pembuatan saluran jaringan reklamasi rawa. Adapun faktor-faktor yang menduduki peringkat 1 sampai 5 adalah (1) cuaca, musim dan gejala alam lainnya, (2) ketersediaan alat, (3) kerusakan alat, (4) keamanan lingkungan dan (5) kecelakaan kerja.
\end{abstract}

Kata kunci : waktu, efektif, reklamasi, penghambat

\section{PENDAHULUAN}

Dalam perencanaan kerja seringkali timbul masalah masalah operasional yang menghambat aktivitas penyelesaian suatu proyek seperti kurangnya sumber daya, alokasi sumber daya yang tidak tepat, keterlambatan pelaksanaan proyek dan masalah-masalah lainnya diluar jadwal dalam rencana kerja (Nicholas, 1990).Keterlambatan proyek bisa berasal dari penyedia jasa maupun dari pengguna jasa maupun pihak lain yang berdampak penambahan waktu dan biaya diluar rencana. Bila keterlambatan berasal dari kontraktor (Penyedia jasa), maka kontraktor bisa dikenai denda, begitu juga bila keterlambatan berasal dari pengguna jasa, maka pengguna jasa akan membayar kerugian yang ditanggung penyedia jasa, yang jumlahnya ditetapkan dalam kontrak sesuai perundang-undangan yang berlaku. 
Pembuatan rencana suatu proyek konstruksi selalu mengacu pada perkiraan yang ada pada saat rencana pembangunan tersebut dibuat, karena itu masalah dapat timbul apabila ada ketidaksesuaian antara rencana yang telah dibuat dengan pelaksanaannya. Sehingga dampak yang sering terjadi adalah keterlambatan waktu pelaksanaan proyek yang dapat juga disertai dengan meningkatnya biaya pelaksanaan proyek tersebut. Berdasarkan hal-hal itu penulis tertarik mengadakan penelitian tentang efisiensi pemberian waktu pelaksanaan pekerjaan oleh pemilik pekerjaan (owner) dan faktor-faktor penghambat pekerjaan.

Untuk penelitian kali ini, akan dilakukan pada proyek pembuatan jaringan reklamasi rawa yang merupakan proyek/pekerjaan penting untuk dilakukan di Kabupaten Kotawaringin Barat, hal ini dilakukan untuk meningkatkan fungsi dan pemanfaatan daerah rawa bagi masyarakat, pembuatan jaringan ini dimaksudkan untuk memberikan sistem pengaturan air yang baik, sehingga dapat membantu masyarakat yang memanfaatkan lahan rawa tersebut, baik untuk pertanian, perikanan, ataupun pemanfaatan yang lain. Tujuan yang ingin dicapai dari analisis ini antara lain adalah: a. Mengevaluasi efektivitas penetapan jangka waktu pelaksanaan proyek. b. Mengetahui waktu efektif rata-rata penyelesaian pekerjaan pembuatan saluran reklamasi rawa. c. Mengetahui faktor-faktor umum yang sering menghambat penyelesaian pekerjaan.

\section{METODE PENELITIAN}

Metode penelitian yang diterapkan untuk tugas akhir ini berbentuk penelitian survei. Penelitian survei pada umumnya dilakukan untuk mengambil suatu generalisasi dari pengamatan yang tidak mendalam. Penelitian yang dilakukan berupa survei dengan cara menjaring pendapat atau persepsi, pengalaman, dan sikap responden mengenai waktu efektif pelaksanaan pekerjaan pembangunan jaringan reklamasi rawa di Kotawaringin Barat.

Pengumpulan data dalam penelitian ini menggunakan metode angket atau kuesioner.
Dimana kuesioner ini merupakan teknik pengumpulan data yang dilakukan dengan cara memberi seperangkat pertanyaan atau pernyataan tertulis kepada responden untuk menjawabnya. Ini merupakan teknik pengumpulan data yang efisien bila peneliti tahu dengan pasti variabel yang diukur dan tahu apa yang bisa diharapkan dari responden.

\section{HASIL DAN PEMBAHASAN}

Dari hasil perhitungan didapat waktu efektif dari masing-masing lokasi pekerjaan, jika diasumsikan waktu mobilisasi dan demobilisasi adalah 14 hari, atau 7 hari untuk mobilisasi dan 7 hari untuk demobilisasi, maka didapat waktu efektif dari masingmasing pekerjaan. Waktu final perhitungan dapat dilihat pada Tabel 1 berikut.

Tabel 1. Waktu Final Perhitungan

\begin{tabular}{|c|c|c|c|c|}
\hline \multirow{2}{*}{ No. } & \multirow{2}{*}{ Nama Pekerjaan } & \multicolumn{3}{|c|}{ Waktu (hari) } \\
\hline & & Kontrak & Efektif & Final \\
\hline 1 & $\begin{array}{l}\text { Pembuatan Saluran Reklamasi } \\
\text { Rawa DR Natai Raya } \\
\text { Kecamatan Arut Selatan }\end{array}$ & 135 & 34 & 48 \\
\hline 2 & $\begin{array}{l}\text { Pembuatan Saluran Reklamasi } \\
\text { Rawa DR Pasir Panjang } \\
\text { (Kelompok Tani Beguruh ) } \\
\text { Kecamatan Arut Selatan }\end{array}$ & 120 & 70 & 84 \\
\hline 3 & $\begin{array}{l}\text { Pembuatan Saluran Reklamasi } \\
\text { Rawa DR Raja Seberang } \\
\text { (Kelompok Tani Kobar Mandiri } \\
\text { ) Kecamatan Arut Selatan }\end{array}$ & 120 & 29 & 43 \\
\hline 4 & $\begin{array}{l}\text { Pembuatan Saluran Reklamasi } \\
\text { Rawa DR Mendawai Seberang } \\
\text { (Kelompok Tani Mendawai } \\
\text { Bersatu) Kecamatan Arsel }\end{array}$ & 120 & 59 & 73 \\
\hline 5 & $\begin{array}{l}\text { Pembuatan Saluran Reklamasi } \\
\text { Rawa DR Sungai Kapitan } \\
\text { (Kelompok Tani Tunas } \\
\text { Harapan) Kecamatan Kumai }\end{array}$ & 120 & 33 & 47 \\
\hline 6 & $\begin{array}{l}\text { Pembuatan Saluran Reklamasi } \\
\text { Rawa DR Mendawai Seberang } \\
\text { (Kelompok Tani Berasau IV) } \\
\text { Kecamatan Arut Selatan }\end{array}$ & 120 & 36 & 50 \\
\hline 7 & $\begin{array}{l}\text { Pembuatan Saluran Reklamasi } \\
\text { Rawa DR Marga Mulya } \\
\text { Kecamatan Pangkalan Banteng }\end{array}$ & 120 & 36 & 50 \\
\hline 8 & $\begin{array}{l}\text { Pembuatan Saluran Reklamasi } \\
\text { Rawa DR Sungai Kapitan } \\
\text { (Gang 2000) Kecamatan Kumai }\end{array}$ & 135 & 70 & 84 \\
\hline 9 & $\begin{array}{l}\text { Pembuatan Saluran Reklamasi } \\
\text { Rawa DR Kumai Hilir } \\
\text { (Sakalading) Kecamatan Kumai }\end{array}$ & 135 & 68 & 82 \\
\hline 10 & $\begin{array}{l}\text { Pembuatan Saluran Reklamasi } \\
\text { Rawa DR Natai Kerbau } \\
\text { Kecamatan Pangkalan Banteng }\end{array}$ & 135 & 99 & 113 \\
\hline 11 & $\begin{array}{l}\text { Pembuatan Saluran Reklamasi } \\
\text { Rawa DR Mendawai Seberang } \\
\text { (Kelompok Tani Harapan } \\
\text { Maju) Kecamatan Arsel }\end{array}$ & 135 & 60 & 74 \\
\hline 12 & $\begin{array}{l}\text { Pembuatan Saluran Reklamasi } \\
\text { Rawa DR Raja Seberang } \\
\text { (Kelompok Tani Mandiri Sejati } \\
\text { ) Kecamatan Arut Selatan }\end{array}$ & 135 & 58 & 72 \\
\hline
\end{tabular}


Tabel 1. (lanjutan)

13 Pembuatan Saluran Reklamasi Rawa DR Raja Seberang

(Kelompok Tani Gerayang Jadi ) Kecamatan Arut Selatan

14 Pembuatan Saluran Reklamasi Rawa DR Riam Durian (Dusun Makarti ) Kecamatan

Kotawaringin Lama

15 Pembuatan Saluran Reklamasi Rawa DR Sungai Sekonyer Kecamatan Kumai

16 Pembuatan Saluran Reklamasi Rawa DR Sulung Kecamatan Arut Selatan

17 Pembuatan Saluran Reklamasi Rawa DR Kumai Hulu (Sungai Bejangkar) Kecamatan Kumai

18 Pembuatan Saluran Reklamasi Rawa DR Mendawai Seberang (Kelompok Tani Berasau IV) Kecamatan Arut Selatan

19 Pembuatan Saluran Irigasi DI Kumpai Batu Atas Kecamatan Arut Selatan

20 Pembuatan Saluran Reklamasi Rawa DR Kotawaringin Hulu

Kecamatan Kotawaringin Lama

21 Pembuatan Saluran Reklamasi Rawa DR Baru (TSM

Pangkalan Bungur) Kecamatan Arsel

22 Pembuatan Saluran Reklamasi Rawa DR Kenambui Kecamatan Arut Selatan

23 Pembuatan Saluran Reklamasi Rawa DR Kubu Kecamatan

Kumai

24 Pembuatan Saluran Reklamasi Rawa DR Sebuai Timur

Kecamatan Kumai

25 Pembuatan Saluran Reklamasi Rawa DR Sungai Kapitan (Kelompok Tani Sintuk Tunas Baru) Kec. Kumai

26 Pembuatan Saluran Reklamasi Rawa DR Sungai Tendang (RT. 01) Kecamatan Kumai

27 Pembuatan Saluran Reklamasi Rawa DR Sungai Cabang

(Teluk Ranggau) Kecamatan Kumai

28 Pembuatan Saluran Irigasi DI Pali Baru Kecamatan Kotawaringin Lama

$\begin{array}{lll}135 & 49 & 63 \\ 135 & 61 & 75 \\ 135 & 39 & 53 \\ 135 & 94 & 108 \\ 135 & 50 & 64 \\ 135 & 26 & 40\end{array}$

$\begin{array}{lll}135 & 27 & 41 \\ 135 & 31 & 45\end{array}$

$135 \quad 28 \quad 42$

$\begin{array}{lll}135 & 83 & 97\end{array}$

$\begin{array}{lll}135 & 34 & 48\end{array}$

$\begin{array}{lll}135 & 88 & 102\end{array}$

$135 \quad 47$

$\begin{array}{lll}135 & 54 & 68\end{array}$

$135 \quad 70 \quad 84$

$135 \quad 62$

$\begin{array}{lll}132 & 53 & 67\end{array}$

Berdasarkan hasil perhitungan pada Tabel didapat waktu pekerjaan efektif ratarata adalah 67 hari, sedangkan waktu kontrak rata-rata didapat adalah 132 hari. Dari hasil tersebut didapat bahwa pekerjaan yang waktu pelaksanaanya dibawah waktu efektif rata-rata adalah 14 pekerjaan, adapun sisanya, yaitu sebanyak 14 pekerjaan memiliki waktu diatas waktu efektif rata-rata, namun masih berada di bawah waktu kontrak rata-rata.

Hal itu menggambarkan bahwa penetapan waktu pekerjaan atau waktu

kontrak cenderung terlalu lama, hal tersebut dapat dilihat dari jumlah pekerjaan yang berada dibawah waktu efektif rata-rata hasil perhitungan mencapai 50\% dari keseluruhan pekerjaan, sedangkan tidak ada pekerjaan yang melebihi waktu kontrak rata-rata.

\section{Analisis Faktor Penghambat Penyelesaian Pekerjaan}

Pada bagian ini dianalisis dan sekaligus dibahas mengenai tingkat kepentingan dari faktor-faktor yang dapat menghambat penyelesaian proyek. Perhitungan ditujukan untuk menghasilkan ranking setiap item dari data yang disajikan pada Tabel 2 .

Tabel 2. Rangking Faktor Kendala Penyelesaian Proyek

\begin{tabular}{|c|c|c|c|}
\hline No & Kendala Penyelesaian Proyek & Mean & Rangking \\
\hline 1 & Cuaca, musim, dan gejala alam lain & 2,4468 & 1 \\
\hline 2 & Ketersediaan alat & 2,2872 & 2 \\
\hline 3 & Kerusakan alat & 2,2234 & 3 \\
\hline 4 & Keamanan lingkungan & 2,1915 & 4 \\
\hline 5 & Kecelakaan kerja & 2,1277 & 5 \\
\hline 6 & Ketersediaan modal awal pekerjaan & 2,0319 & 6 \\
\hline 7 & Pekerjaan bertepatan bulan ramadhan & 1,9043 & 7 \\
\hline 8 & Akses alat ke lokasi proyek & 1,8936 & 8 \\
\hline 9 & $\begin{array}{l}\text { Ketersediaan material (bahan bakar } \\
\text { alat) }\end{array}$ & 1,7766 & 9 \\
\hline 10 & Keahlian tenaga kerja (operator) & 1,7660 & 10 \\
\hline 11 & Terjadi perubahan perencanaan & 1,7340 & 11 \\
\hline 12 & Produktifitas kerja alat tidak optimal & 1,6277 & 12 \\
\hline 13 & Terjadi kesalahan perencanaan & 1,6064 & 13 \\
\hline 14 & Kesalahan membaca gambar & 1,3830 & 14 \\
\hline 15 & Permasalahan dengan masyarakat & 1,2021 & 15 \\
\hline 16 & $\begin{array}{l}\text { Kondisi fisik dilapangan yang } \\
\text { berbeda dengan kondisi di } \\
\text { perencanaan }\end{array}$ & 1,2021 & 16 \\
\hline 17 & Aksi mogok kerja & 1,1489 & 17 \\
\hline 18 & $\begin{array}{l}\text { Perlindungan kawasan sekitar lokasi } \\
\text { (Hutan lindung,tanah adat,dll) }\end{array}$ & 1,1170 & 18 \\
\hline 19 & Penggantian tenaga kerja baru & 1,0000 & 19 \\
\hline 20 & Pembebasan lahan & 0,9681 & 20 \\
\hline
\end{tabular}

Selanjutnya untuk memberi penilaian pada harga rata-rata dibuat batasan sebagai berikut: harga rata-rata kurang dari 0,50 tidak berpengaruh, 0,51-1,49 agak berpengaruh, 1,50-2,49 berpengaruh, 2,50-3,00 sangat berpengaruh, sebagaimana terlihat pada Tabel 3 di bawah ini.

Tabel 3. Penjelasan Arti Interval Nilai Mean

\begin{tabular}{ccc}
\hline Interval Nilai & Arti & Frekuensi \\
\hline$<0,50$ & Tidak berpengaruh & $\mathbf{0}$ \\
$0,51-1,49$ & Agak berpengaruh & $\mathbf{7}$ \\
$1,50-2,50$ & Berpengaruh & $\mathbf{1 3}$ \\
$2,51-3,00$ & Sangat berpengaruh & $\mathbf{0}$ \\
\hline \multicolumn{2}{c}{ Jumlah } & $\mathbf{2 0}$ \\
\hline Sumber : Furqon (1997) &
\end{tabular}


Untuk pertanyaan yang bernilai $0,51-$ 1,49 , atau dengan arti agak berpengaruh terdapat 7 pertanyaan, atau $35 \%$ dari total 20 faktor yang diberikan. Faktor yang termasuk dalam kategori ini dapat dilihat pada Tabel 4 berikut.

Tabel 4. Faktor dengan Kategori Agak Berpengaruh

\begin{tabular}{|c|c|c|c|}
\hline No & Faktor & Mean & Rangking \\
\hline 1 & Kesalahan membaca gambar & 1,3830 & 14 \\
\hline 2 & $\begin{array}{l}\text { Permasalahan dengan } \\
\text { masyarakat }\end{array}$ & 1,2021 & 15 \\
\hline 3 & $\begin{array}{l}\text { Kondisi fisik dilapangan yang } \\
\text { berbeda dengan kondisi di } \\
\text { perencanaan }\end{array}$ & 1,2021 & 16 \\
\hline 4 & Aksi mogok kerja & 1,1489 & 17 \\
\hline 5 & $\begin{array}{l}\text { Perlindungan kawasan sekitar } \\
\text { lokasi (Hutan lindung,tanah } \\
\text { adat,dll) }\end{array}$ & 1,1170 & 18 \\
\hline 6 & Penggantian tenaga kerja baru & 1,0000 & 19 \\
\hline 7 & Pembebasan Lahan & 0,97 & 20 \\
\hline
\end{tabular}

Sedangkan yang masuk kategori berpengaruh terdapat 13 faktor seperti teraji dalam Tabel 5.

Tabel 5. Faktor Dengan Kategori berpengaruh

\begin{tabular}{clcc}
\hline No & \multicolumn{1}{c}{ Faktor } & Mean & Rangking \\
\hline 1 & Cuaca, musim, dan gejala alam & 2,4468 & 1 \\
& lainnya & & \\
2 & Ketersediaan alat & 2,2872 & 2 \\
3 & Kerusakan alat & 2,2234 & 3 \\
4 & Keamanan lingkungan & 2,1915 & 4 \\
5 & Kecelakaan kerja & 2,1277 & 5 \\
6 & Ketersediaan modal awal & 2,0319 & 6 \\
& pekerjaan & & \\
7 & Pekerjaan bertepatan bulan & 1,9043 & 7 \\
& ramadhan & 1,8936 & 8 \\
8 & Akses alat ke lokasi proyek & 1,7766 & 9 \\
9 & Ketersediaan material (bahan bakar & & \\
& alat) & 1,7660 & 10 \\
10 & Keahlian tenaga kerja (operator) & 1,7340 & 11 \\
11 & Terjadi perubahan perencanaan & 1,6277 & 12 \\
12 & Produktifitas kerja alat tidak & & \\
& optimal & 1,6064 & 13 \\
\hline
\end{tabular}

Dalam penelitian kali ini tidak terdapat faktor yang mendapat skor diatas 2,50 sehingga tidak ada faktor yang masuk kategori sangat berpengaruh.

\section{Pembahasan Faktor Penghambat}

Pembahasan faktor penghambat rangking 1 sampai 5 sebagai berikut.

1. Cuaca, musim, dan gejala alam lainnya

Dalam penelitian kali ini faktor cuaca, musim, dan gejala alam lainnya mendapat rangking petama dengan nilai mean 2,4468. Hal ini diperkuat oleh Muhammad Ridha (mahasiswa Jurusan
Teknik Sipil Fakultas Teknik Sipil Dan Perencanaan Institut Teknologi Sepuluh Nopember, Surabaya 2011) yang menyatakan bahwa Cuaca, musim, dan gejala alam lainnya adalah faktor yang mempengaruhi pekerjaan/proyek.

penjawalan

Faktor cuaca cukup mempengaruhi pekerjaan pembuatan saluran reklamasi rawa, hal tersebut karena jika curah hujan terlalu tinggi, besar kemungkinan daerah rawa yang akan dikerjakan tergenang air yang cukup dalam, hal tersebut akan menyusahkan pengerjaan.

2. Ketersediaan alat

Menurut Andi et al. (2003) faktor-faktor yang potensial untuk mempengaruhi waktu pelaksanaan konstruksi, yang terdiri dari tujuh (7) hal, salah satunya adalah Faktor peralatan, dengan sub faktor ketersediaan alat. Hal ini juga terlihat dalam penelitian kali ini, faktor ketersediaan alat dalam penelitian kali ini termasuk dalam kategori faktor yang berpengaruh, dengan nilai mean 2,2872. Minimnya jumlah pemborong yang memiliki alat berat berupa Exavator sendiri, menyebabkan para pemborong harus menyewa alat tersebut dari dinas PU atau pihak lain, hal tersebut dapat menjadi hambatan dalam pengerjaan jika pemborong tidak punya kesiapan dalam hal alat berat, karena dengan banyaknya pekerjaan yang menggunakan alat berat berupa excavator tersebut dapat terjadi kemungkinan pemborong yang tidak memiliki alat berat sendiri harus mengantri untuk dapat menyewa alat berat tersebut, sehingga waktu pelaksanaan pekerjaan akan tertunda.

3. Kerusakan alat

Idzurnida Ismael (Dosen Jurusan Teknik Sipil, Fakultas Teknik Sipil dan perencanaan institut Teknologi padang) mengemukakan, ada beberapa variabel yang dominan dari faktor risiko yang paling yang berdampak pada keterlambatan proyek konstruksi, salah satunya adalah kerusakan alat. Kerusakan alat menjadi faktor berpengaruh yang ketiga, yaitu dengan nilai mean 2,2234. 
Kerusakan alat (excavator) menjadi penghambat dalam pekerjaan, jika terjadi kerusakan pada alat berat, perbaikannya memerlukan waktu yang tidak sebentar dan biaya yang cukup besar, hal tersebut dikarenakan perbaikan alat berat yang cukup rumit dan ketersediaan suku cadang dari alat berat tersebut, jika suku cadang tersebut tidak tersedia maka harus menunggu pesanan terlebih dahulu, selain itu permasalahan yang terjadi juga pada keterbatasan mekanik alat berat yang berpengalaman yang ada di daerah Kotawaringin Barat.

4. Keamanan lingkungan

Selain faktor peralatan Andi et al. (2003) juga mengemukakan faktor-faktor yang potensial untuk mempengaruhi waktu pelaksanaan konstruksi adalah keamanan lingkungan.Keamanan lingkungan pada penelitian kali ini termasuk dalam kategori berpengaruh dengan nilai mean 2,1915, keamanan lingkungan yang dimaksud adalah kondisi yang aman dan kondusif dilokasi pekerjaan, tidak terjadi konflik ataupun kerusuhan. Keamanan juga mencakup keamanan alat berat dan material lain dari pencurian dan pengrusakan. Biasanya alat berat yang mengerjakan saluran reklamasi rawa pada malam hari akan ditinggal di lokasi pekerjaan yang terkadang jauh dari base camp atau rumah penduduk, hal tersebut menyebabkan pencurian komponen dan bahan bakar sering terjadi, mahalnya suku cadang dan bahan bakar dari alat berat tersebut membuat alat berat yang di diparkir dilokasi pekerjaan menjadi incaran pihak tak bertanggung jawab. Maka keamanan lokasi pekerjaan menjadi hal yang sangat berpengaruh dalam penyelesaian pekerjaan.

5. Kecelakaan kerja

Masih menurut Andi et al. (2003), faktor kecelakaan kerja juga termasuk dalam faktor yang potensial untuk mempengaruhi waktu pelaksanaan Pekerjaan. Dalam penelitian ini kecelakaan kerja menjadi faktor penghambat penyelesaian pekerjaan rangking 5, yaitu dengan nilai mean
2,1277. Kecelakaan kerja yang dimaksud adalah kecelakan yang menimpa pekerja atau pun alat berat, kecelakaan yang menimpa pekerja dirasa cukup kecil pengaruhnya pada pekerjaan, karena jika terjadi kecelakaan pada operator alat berat biasanya ada asisten dari operator yang akan menggantikan. Lain halnya jika kecelakaan terjadi pada alat berat itu sendiri, seperti alat berat yang terbalik atau alat berat yang tenggelam, penanganannya akan memerlukan waktu yang cukup lama, karena biasanya harus mendatangkan alat berat bantuan untuk menanganinya,tentunya hal tersebut akan menunda pekerjaan dalam waktu yang cukup lama.

\section{KESIMPULAN}

1. Waktu efektif rata-rata penyelesaian pekerjaan pembuatan saluran reklamasi rawa adalah 67 hari.

2. Jika didasarkan pada hasil perhitungan hasil kuesioner waktu pelaksanaan proyek yang diberikan masih terlalu lama, hal itu dapat dilihat dari perbandingan antara waktu efektif rata-rata dengan waktu kontrak rata-rata yaitu 67 hari, sedangkan waktu kontrak rata-rata didapat adalah 132 hari.

3. Dalam penelitian kali ini tidak ada faktor yang masuk kategori tidak berpengaruh, dengan demikian disimpulkan bahwa faktor-faktor tersebut mempunyai peranan yang hampir merata dalam menghambat penyelesaian pekerjaan pembuatan saluran jaringan reklamasi rawa.

4. Faktor-faktor yang menduduki peringkat 1 sampai dengan 5 adalah (1) cuaca, musim, dan gejala alam lainnya, (2) ketersediaan alat, (3) kerusakan alat, (4) keamanan lingkungan dan (5) kecelakaan kerja.

\section{SARAN}

1. Bagi pemilik proyek (owner) disarankan agar mengkaji kembali efektifitas penetapan waktu pelaksanaan pekerjaan (waktu kontrak), sehingga didapat waktu kontrak yang lebih efisien.

2. Bagi semua pihak yang terlibat dalam pekerjaan disarankan agar mempertimbangkan faktor-faktor yang 
telah diuraikan diatas, agar segala sesuatu yang dapat menghambat penyelesaian pekerjaan dapat di hindari, ataupun dapat diantisipasi secepatnya, sehingga tidak menghambat pekerjaan.

3. Karena hasil penelitian didasarkan dari pendapat dan jawaban dari responden, penelitian ini cenderung masih bersifat subjektif, untuk penelitian selanjutnya disarankan agar menggunakan metode lain, agar dapat dilihat perbedaan yang didapat dari penelitian dengan berbagai metode.

\section{DAFTAR PUSTAKA}

Abdurrahman M. Asad Nur, dkk, 2012, Analisa Pengelolaan Risiko Proyek-Proyek

Pengairan, Universitas Hasanuddin, Makassar.

Bulls. 1998, Faktor - Faktor Penyebab

Kegagalan Pelaksanaan Proyek, Perancis.

Canada Survey, KPMG, 1997, Kegagalan Pelaksanaan Proyek, Canada.

Dinas PU Daerah Kab. Kobar, 2013, Dokumen Kontrak Pekerjaan, Kabupaten Kotawaringin Barat.

Dipohusodo, I., 1996, Manajemen Proyek Dan Konstruksi Jilid 1, Gramedia Pustaka Utama, Jakarta.

Furqon, 1997, Statistika Terapan Untuk Penelitian, CV. Alfabeta, Bandung.

Handoko, T.H., 1999, Dasar-Dasar Manajemen Produksi dan Operasi, Edisi Pertama, BPFE, Yogyakarta.
Haryanto, 2012, Pendekatan Jenis dan Metode Penelitian.

Lock, D., 1990, Manajemen Proyek, Berikut Kepres 29/30 Tahun 1984, Edisi Ke 3, Salemba Empat, Jakarta.

Moleong, L. J., 1988, Metodologi Penelitian Kualitatif, PT. Remaja Rosdakarya, Bandung.

Project Management Institute, 2004, A Guide To The Project Management Body Of Knowledge, 3rd Edition, E-Book Project Management Institute, USA.

Reksohadipradjo, S., 1997, Manajemen Proyek, BPFE, Yogyakarta.

Rina A., dkk, 2013, Faktor-Faktor Risiko Keterlambatan Pelaksanaan Pekerjaan Konstruksi di Bidang Sungai Dinas Pengairan Aceh. Universitas Syiah Kuala, Aceh.

Soeharto, I., 2001, Manajemen Proyek : Dari Konseptual Sampai Operasional, Erlangga, Jakarta.

Suyatno, 2010, Analisis Faktor Penyebab Keterlambatan Penyelesaian Proyek Gedung, Tesis, Universitas Diponegoro, Semarang.

The Standish Group, 1995, Chaos Report, 5 Penyebab Utama Kegagalan Implementasi Proyek. 